Izecksohn, E. e S. P. Carvalho-e-Silva. 2001. Anfíbios do Município do Rio de Janeiro. Rio de Janeiro. Editora UFRJ. 148 pp.

ISBN: 85-7108-243-X

Formato: 14 x $21 \mathrm{~cm}$

Preço aproximado: $\mathrm{R} \$ 20,00$

Anfíbios do Município do Rio de Janeiro, de autoria de Eugênio Izecksohn e Sérgio Potsch de Carvalho e Silva, publicado pela Editora UFRJ, é uma publicação acessível, muito bem apresentada e organizada e direcionada a leigos, iniciantes e estudiosos da biologia dos anfíbios. Ainda que de abrangência geográfica restrita, retrata a fauna de anfíbios de uma área importante e amplamente estudada por notáveis zoólogos brasileiros, como Alípio de Miranda Ribeiro, Antenor Leitão de Carvalho, Adolpho e Bertha Lutz e Werner C. A. Bokermann.

A publicação encontra-se dividida em cinco capítulos, que tratam de introduzir o grupo de estudo, a área de estudo e sua importância, a lista das espécies e possíveis medidas conservacionistas. Fica claro, diante da organização do trabalho, que a lista das espécies é o item mais importante da obra, sendo, os demais capítulos, bastante breves. A lista é apresentada com ilustrações e comentários sobre a história natural de cada uma das espécies. Como era de se esperar para um trabalho com esse público-alvo, não são tecidos comentários mais profundos sobre a taxonomia dos grupos.

A lista de referências bibliográficas reúne algumas contribuições importantes ao estudo dos anfíbios, não só do município do Rio de Janeiro, mas de todo o território nacional. Um índice, no final do trabalho, facilita o acesso às informações disponíveis para cada espécie e sua ilustração. Cabe ressaltar o ótimo Prefácio, de autoria de Ulisses Caramaschi, que fornece ao leitor uma breve perspectiva histórica do estudo dos anfíbios no Brasil, seguida da apresentação da área de abrangência do trabalho, da importância dos anuros para o ambiente e da apresentação dos autores.
No capítulo Anfíbios, são apresentadas as características diagnósticas mais conspícuas para cada ordem de anfíbios atuais, além de breves noções de diversidade, biologia reprodutiva e principais presas e predadores. Uma ilustração que contemplasse o ciclo reprodutivo dos anuros nesse capítulo seria bem-vinda.

No capítulo O Município do Rio de Janeiro e os Anfíbios, encontram-se a justificativa para a elaboração de uma lista de espécies de anfíbios para o município, uma apresentação geral das áreas remanescentes de Mata Atlântica na região e a situação do conhecimento da fauna em cada uma delas. Também são citadas particularidades, como a ocorrência de espécies introduzidas ou que toleram ambientes antrópicos. Nesse capítulo, existe a referência a um mapa, de grande ajuda àquele leitor não familiarizado com a área de estudo.

Em Material e Métodos, os autores apresentam os critérios utilizados para a elaboração da lista de espécies e a definição de alguns padrões de comparação, como as classes de tamanho. Considero esse capítulo essencial, pois sua ausência em muitos trabalhos desse tipo faz com que o leitor permeie sua leitura de pontos de interrogação.

O capítulo Espécies Assinaladas, a principal parte do livro, compreende as fichas completas de todas as espécies registradas no município do Rio de Janeiro em ordem alfabética de famílias, gêneros e espécies, todas ilustradas por fotografias em preto-e-branco do animal em vista dorsal. Cada espécie é apresentada com seu nome científico, autor da descrição, citação da prancha colorida e nome popular (não padronizado). Abaixo do nome de cada categoria taxonômica, há, entre parênteses, informações sobre caracteres externos óbvios que podem ser utilizados para diagnosticar o grupo. Embora interessantes, poluem de alguma forma a estampa, tornando pouco destacados os nomes dos táxons. Os comentários sobre a história natural de cada uma das espécies incluem basicamente caracteres diagnósticos externos, informações 
sobre biologia reprodutiva, distribuição geográfica e abundância no município. Apesar de uma tentativa bem intencionada, a descrição das vocalizações das espécies é quase sempre frustrante. Este não é certamente um problema dos autores ao descrevê-las, mas sim da particularidade com que um mesmo som pode ser descrito por diferentes indivíduos.

O capítulo Medidas Conservacionistas, onde são citadas as espécies em situação crítica no município, é de grande importância e poderia ter sido mais explorado. O problema do declínio mundial de populações de anfíbios, por exemplo, é apresentado sem maior desenvolvimento. Contudo, o capítulo não deixa de nos informar sobre o mais importante: a primeira e mais urgente medida para a preservação das espécies de anfíbios do município (e de qualquer outro lugar) é a preservação de seu hábitat.

O desapontamento inicial diante das ilustrações em preto-e-branco da lista comentada é totalmente substituído pelo prazer de contemplar as boas fotografias das pranchas coloridas, onde 64 das 69 espécies referidas estão ilustradas.
Arrisco-me a dizer que as fotografias em pretoe-branco, em que os exemplares apresentam-se na posição típica de fixação, foram utilizadas como um padrão para facilitar comparações entre as espécies.

\section{Anfíbios do Município do Rio de Janeiro} é uma reunião completa e de qualidade dos dados mais importantes sobre a biologia de 69 das cerca de 500 espécies de anfíbios encontradas em território nacional. Retrata o que se conhece e o que falta conhecer da biologia de um grupo fascinante em uma área extremamente importante e ainda pouco explorada, como é o caso da Mata Atlântica. Será, com certeza, amplamente utilizado em trabalhos de inventários de fauna e servirá de ponto de partida e incentivo para publicações de mesmo cunho que tratem de outras áreas. Deve, sem dúvida, constar da biblioteca de qualquer leigo ou profissional que se interesse por anfíbios.

\section{Vanessa K. Verdade \\ Departamento de Zoologia \\ Universidade de São Paulo}

Marques, O. A. V., A. Eterovick e I. Sazima. 2001. Serpentes da Mata Atlântica - guia ilustrado para a Serra do Mar. Ribeirão Preto. Holos Editora. 184 pp.

ISBN: 85-86699-23-3

Formato: $20 \times 12 \mathrm{~cm}$

Preço aproximado: $\mathrm{R} \$ 20,00$

Os herpetólogos, em especial aqueles interessados em serpentes, só tiveram a ganhar com a publicação deste guia pela Holos Editora. $\mathrm{Na}$ mais feliz combinação entre experiência e juventude, Otávio A. V. Marques, André Eterovic e Ivan Sazima nos brindaram com uma obra que, além de fotografias de excelente qualidade, é rica em informações sobre a biologia das serpentes da Mata Atlântica da Serra do Mar.

O livro se inicia com uma justa homenagem a Joaquim Cavalheiro, funcionário aposentado do Instituto Butantan, que muito contribuiu e ainda contribui para os estudos sobre as serpentes brasileiras. Em seguida, os autores abrem a Introdução apresentando como principal objetivo da obra o auxílio à identificação de ofídios com ocorrência na Mata Atlântica da Serra do Mar. Esse trecho de terras elevadas, que se estende do estado do Rio de Janeiro até Santa Catarina, e a cobertura florestal a ele associada são então descritos sucinta e ricamente. Ênfase especial é dada ao triste fato de restarem, no Brasil, somente cerca de $8 \%$ da cobertura original desse tipo de floresta.

Ainda na Introdução, os autores fornecem uma excelente caracterização geral das serpentes, enriquecida por fotografias extremamente ilustrativas. São explicados os tipos de dentição, os órgãos dos sentidos, as famílias e suas 